\title{
Post Merger and Acquisition and Performance of Deposit Money Banks in Nigeria
}

\author{
Imeokparia, Lawrence Ph.D, FCA \\ Department of Financial Studies College of Management Science Redeemer's University Km 46/ 48 Lagos/ \\ Ibadan Express way Redemption City, Mowa Ogun State, Nigeria
}

\begin{abstract}
Mergers and acquisitions as a phenomenon is implemented to strengthen the banking system, embrace globalization, improve healthy competition, exploit economies of scale, adopt advanced technologies, raise efficiency and improve profitability. The world globalization has led to world financial crisis which has significantly affected the banking industry and has consequently increased the need for mergers and acquisitions $(M \& A)$ in the consolidation of deposit money banks. One of the major policies introduced to solve these financial problems is by consolidation through mergers and acquisitions. This study explored the impact of post mergers and acquisitions on the performance of deposit money banks in Nigeria. The study adopted a cross sectional survey design with a total population of 22 deposit money banks in Nigeria. A sample of 10 banks was randomly selected from the above population. The study used the secondary sources to extract data from the Annual Reports of the selected banks for a period of five (5) years (2008-2012). Simple regression analysis technique was used for data analyses. The study revealed that as at the end of year 2012, the average capital base of the sampled banks in the post Merger period showed a total of (N 1.76 Trillion). This is an improvement from the recent work of Oghojafor (2012) in which average capital base stood at (N 6,358.76 Million). The study revealed an insignificant but positive relationship between post mergers and acquisitions capital base (PMACB) and dividend per share $(D P S)$ with $(P=0.985$ i.e. $P>0.05)$, earnings per share (EPS) with $(P=0.803$ i.e. $P>0.05)$, return on assets $(R O A)$ with $(P=0.859$ i.e. $P>0.05)$ and return on capital employed with $(P=0.666$ i.e. $P>0.05)$. This study concluded that post merger and acquisition has no significant effect on dividend per share of shareholders, their earnings per share, return on assets and return on capital employed. In a broad perspective, this study further revealed that there is a reduction in the degree of global banking crisis over the years and thus reduction in the general banking failure particularly in Nigeria. This is made possible through mergers and acquisition process which consecutively resulted in increased capital base of banking industry in Nigeria. The study recommended that equal considerations should be given to both micro and macro prudential guidelines, in order to ensure sound and stable banking system. Also, deposit money banks should incorporate into their banking policy other factors such as credit discipline, corporate culture, and management information system so as to ensure increase in their earnings ability.

Keyword: Merger, Acquisition, Banking sector, Performance.
\end{abstract}

\section{Introduction}

The 2008 economic downturn and the recent global banking crisis lead to the growing need for bank consolidation through mergers and acquisitions in Nigeria. The knowledge of this will assist the deposit money banks in determining the extent to which capital base enhances their specific areas of performances. Uyen, (2011) asserts that in order to cope with the complexity and a mix of risk exposure to banking system properly, responsibly, beneficially and sustainably, it is of great importance to evaluate the overall performance of banks by implementing a regulatory banking supervision framework.

This study analyzed the performance of the Nigerian banking industry from 2008 to 2012. It has coverage of some selected banks out of all the banks that operated in Nigeria during the year 2008 to 2012 . Prior to the consolidation exercise in the year 2005, there were 89 banks in existence and after the recapitalization the banks were consolidated into 25 banks and later reduced to 24 by another merger. Currently, there exist 22 banks, out of which seven (7) will be used for this study.

\subsection{Research Objective}

The main objective of this study is to assess the impact of post merger and acquisition (M\&A) on the performance of the Nigerian Banking industry. However, the study identifies the following specific objectives which are; to

i.) establish the relationship between post M\&A capital base and return on dividend per share of deposit money banks,

ii.) determine the relationship between post $M \& A$ capital base and earnings per share on deposit money banks, 


\subsection{Research Questions}

The study however, intends to answer the following specific research questions:

i.) What significant relationship exists between post M\&A capital base and dividend per share of deposit money banks in Nigeria?

ii.) What is the relationship between post M\&A capital base and earnings per share of deposit money banks in Nigeria

\subsection{Research Hypotheses}

The following hypotheses were formulated from the objectives which will be verified in the course of this research work and will guide us in finding the solution to the problem that is induced in this research work:

\section{Hypothesis One:}

$H_{0}$ : There is no significant relationship between post merger and acquisition (M\&A) capital base and dividend per share of deposit money banks in Nigeria.

$H_{l}$ : There is significant relationship between post merger and acquisition (M\&A) capital base and dividend per share of deposit money banks in Nigeria.

\section{Hypothesis Two:}

$H_{0}$ : There is no significant relationship between post merger and acquisition (M\&A) capital base and earnings per share of deposit money banks in Nigeria.

$H_{l}$ : There is significant relationship between post merger and acquisition (M\&A) capital base and earnings per share of deposit money banks in Nigeria.

\subsection{Operationalization Of Variables}

The model to be used for this study is a linear regression model. The model was used to measure the relationship between Post M\&A Capital Base (PMACB) and performance of deposit money banks. The performance indicators used include: dividend per share (DPS), earnings per share (EPS), return on asset (ROA) and return on capital employed (ROCE).

The general regression equations in four (4) different equations for this study are as follows:

$$
\begin{aligned}
& Y_{1}=a_{1}+b_{1} X \ldots \ldots . .1 \\
& Y_{2}=a_{2}+b_{2} X \ldots \ldots . .2 \\
& Y_{3}=a_{3}+b_{3} X \ldots \ldots .3 \\
& Y_{4}=a_{4}+b_{4} X \ldots \ldots .4
\end{aligned}
$$

Thus, $\mathrm{Y}_{1}, \mathrm{Y}_{2}, \mathrm{Y}_{3}$ and $\mathrm{Y}_{4}$ represent DPS, EPS, ROA and ROCE respectively. On the other hand, ' $\mathrm{X}$ ' represents PMACB.

The ' $\mathrm{a}_{1}$ to $\mathrm{a}_{4}$ ' and ' $\mathrm{b}_{1}$ to $\mathrm{b}_{4}$ ' represent the Constants and the Coefficients respectively of each equation, from equation 1 to 4 .

Hence, for the purpose of the study, the model is stated thus:

$$
\begin{aligned}
& Y_{D P S}=a_{D P S}+b_{\text {DPS }} \mathrm{X}+\mu \ldots \ldots .1 \\
& Y_{E P S}=a_{\text {EPS }}+b_{\text {EPS }} X+\mu \ldots \ldots . .2 \\
& Y_{\text {ROA }}=a_{\text {ROA }}+b_{\text {ROA }} X+\mu \ldots \ldots .3 \\
& Y_{\text {ROCE }}=a_{\text {ROCE }}+b_{\text {ROCE }} X+\mu \ldots .4
\end{aligned}
$$

In terms of functional relationships, the model is also as follows:

$$
\begin{aligned}
\mathrm{DPS} & =\mathrm{f}(\text { PMACB }) \ldots \ldots . .1 \\
\mathrm{EPS} & =\mathrm{f}(\text { PMACB }) \ldots \ldots \ldots . .2 \\
\mathrm{ROA} & =\mathrm{f}(\text { PMACB }) \ldots \ldots . . .3 \\
\mathrm{ROCE} & =\mathrm{f}(\text { PMACB }) \ldots \ldots . . .4
\end{aligned}
$$

Where:

PMACB $=$ Ordinary Share Capital (OSC), Share Premium (SP), Reserves (RSVS)

Or

PMACB $=$ Shareholders' Fund (SHF)

From these functional relationships, the following linear regression models are also specified.

$$
\begin{gathered}
\text { DPS }=\alpha_{0}+\alpha_{1} \text { OSC }+\alpha_{2} \text { SP }+\alpha_{3} \text { RSVS } \ldots \ldots \ldots . .1^{1} \\
\text { EPS }=\beta_{0}+\beta_{1} \text { OSC }+\beta_{2} \mathrm{SP}+\beta_{3} \text { RSVS }+\mu \ldots \ldots \ldots \ldots .2^{1} \\
\text { ROA }=\pi_{0}+\pi_{1} \text { OSC }+\pi_{2} \mathrm{SP}+\pi_{3} \text { RSVS }+\ldots \ldots \ldots \ldots 3^{1} \\
\text { ROCE }=\gamma_{0}+\gamma_{1} \mathrm{OSC}+\gamma_{2} \mathrm{SP}+\gamma_{3} \text { RSVS }+\mu \ldots \ldots \ldots . .4^{1}
\end{gathered}
$$

Where:

$\alpha_{0}, \beta_{0}, \pi_{0}$ and $\gamma_{0}$ are intercepts of the regression lines. 
$\left(\alpha_{1}, \alpha_{2}, \alpha_{3}\right) ;\left(\beta_{1}, \beta_{2}, \beta_{3}\right) ;\left(\pi_{0}, \pi_{1}, \pi_{2}, \pi_{3}\right) ;$ and $\left(\gamma_{1}, \gamma_{2}, \gamma_{3}\right)$ are slope coefficients to capture the nature and effect of the relationship between the variables.

$\mu$ is the error term.

\section{Literature Review}

Gazia, Jamil S; Najmus, and Sahar S; (2013) described Banking sector as an integral part of an economy. This sector according to them plays a key role in the well-being of the economy. Thus, the sector according to them is tending towards high complexity as a result of globalization. According to Khadijat, Abdulrasheed, Ramat, and Oyebola, (2012), the banking industry in Nigeria has witnessed a tremendous growth over the past years. This assertion is borne out of the number of banks and bank branches, their total deposits, total investments, total loans and advances and the profitability of the industry. For instance, the number of banks in Nigeria increased from 11 in 1960 to 45 at the end of 1990. According to Nigerian Deposit Insurance Corporation (1991) Annual Report and Statement of Accounts, the number of banks has increased from 45 in 1986 to 119 at the end of 1991, representing an increase of more than two folds. These 119 banks at end of 1991 were made up of 25 State- Government owned Commercial banks, 8 Federal-Government owned Commercial Banks, 32 Privately-owned Commercial Banks, 8 Federal/State-Government owned Merchant Banks and 46 Privately-owned Merchant Banks. The introduction of the Structural Adjustment Programme (SAP) in 1986 as an economic reform package was designed to liberalize the economy with emphasis on the financial system. The SAP era witnessed many policy measures that have continued to shape developments in the sector till the present day. As revealed by Central Bank of Nigerian Annual Report,( 2003), the number of licensed banks shot up from 119 in 1991 to 120 in 1992 and in the same year, the sector recorded the existence of over 500 finance houses, 121 Bureau de change and about 300 community banks, among others. The numbers of banks reduced to 24 in the year 2004 as a result of re-capitalization programme of the Federal Government. Adegbaju and Olokoyo (2008) observed that the concept of recapitalization and capital base is a familiar concept in Nigeria. According to them, bank recapitalization is not a new phenomenon. The colonial government with effect from 1958 after the first banking ordinance of 1952 shored up the capital base requirement of foreign banks from $£ 200,000$ to $£ 400,000$. Since then, the issue of recapitalization of banks gained much popularity particularly in Nigeria. There seems to be continuous occurrence of bank recapitalization in the whole world at large since the advent of interdependency amongst the global economies. Bakare (2011), disclosed that, the first round of recapitalization was in 1952, when the colonial government then raised the capital requirement for banks especially the foreign commercial banks to $£ 12,500$. Ever since then, the issue of banks recapitalization has been a continuous occurrence not only in Nigeria, but generally around the world especially as the world continues national economies. According to him, in 1969, the paid-up capital was increased from $£ 12,500$ $£ 300,000.00$. Soyinbo and Adekanye (1992) and Adam (2003), in Bakar ( 2011), traced recapitalization to take its roots from bank failures. According to them, most banks in Nigeria failed as a result of inadequate capital base, mismanagement of funds, overtrading, lack of regulation and control; and unfair competition from the foreign banks. Thus, recapitalization is one of the banking reforms to tackle these problems.

According to Bakare( 2011:1), "The Nigerian banking system today is fragile and marginal. The system faces enormous challenges which if not addresses urgently, could snowball into a crisis in the near future". Demirguc-kunt and Levine (2003) argued in the same literature that, recapitalization drives bank consolidation (mergers and acquisitions) so that increased concentration goes hand-in-hand with efficiency improvements, Boyd and Runkle (1993), Sulaiman (2004) and Imala (2005) buttressed this argument. They stressed further that consolidated banking system enhances profits efficiency, and lower bank fragility. More importantly, high profits arising from this provides a buffer against adverse shocks and increases the franchise value of the banks.

Adegbaju and Olokoyo,( 2008:5), stated thus; "the objectives of banking system are to ensure price stability and facilitate rapid economic development. Regrettably these objectives have remained largely unattained in Nigeria as a result of some deficiencies in our banking system, these include; low capital base, as average capital base of Nigeria banks was $\$ 10$ million which is very low, a large number of small banks with relatively few branches, the dominance of a few banks, poor rating of a number of banks, weak corporate governance evidence by inaccurate reporting and non compliance with regulatory requirements, insolvency as evidence by negative capital adequacy ratios of some banks, eroded shareholders fund caused by operating losses, over dependence on public sector deposit, and foreign exchange trading and the neglect of small and medium scale private savers. The Nigeria banking sector plays marginal role in the development of the real sector." Also, Adegbaju and Olokoyo,(2008:5). in the same literature observed thus "many banks appear to have abandoned their essential intermediation role of mobilizing savings and inculcating banking habit at the household and micro enterprise levels. The indifference of banks towards small savers, particularly at the grassroots level, has not only compounded the problems of low domestic savings and high bank lending rates in the 
country, it has also reduced access to relatively cheap and stable funds that could provide a reliable source of credit to the productive sectors at affordable rates of interest."

In view of the capital base directive of the Nigerian banking sector by the apex bank, Oghojafor, (2012:2), states thus, "It is not an understatement to state that, the Nigerian banking reform exercise and consolidation between 2004 and December 2005 later ended up becoming a serious reflection of merger and acquisition. The reason being that, the major strategy of escaping the sledge hammer of the CBN (should the 25 billion Naira capital base not met) was for the banks to hurriedly pool their resources together to meet the book value of the minimum capital base. Since the essence of any reform is to bring about greater efficiency not only to the organizations but also their contributions to economic development of the nation, then it became important to raise a fundamental question in this study about whether the consolidation exercise (merger and acquisition) has impacted positively on the performance of the bank and the economy in general."

Bakare (2011) opined that, the bone of contention remains the adoption of new recapitalization policy, in which banks that do not meet the capital requirement must either merge with the stronger or bigger banks or get acquired by same stronger banks. Dogan and Yildiz (2013) examined the impact of the size of board of directors on bank performance, using a sample of 12 banks data, which were involved in the Istanbul Stock Exchange (ISE) for the period 2005-2010. Their research method majorly consists of regression and correlation in conducting the analyses of the research. Their findings however show negative and statistically significant relationship between some accounting based performance indicators such as Return on Assets (ROA) along with Return on Equity (ROE) and the size of board of directors of the selected banks. The study also shows the evidence of negative and statistically non-significant relationship between Tobin's Q as a market based performance indicator and size of the boards. All together, the study discovers positive relationship between ROA and ROE with banks" "Free Float Ratio", while in contrast, the relationship between ROA and ROE with "Number of Employees per Branch and Risk" is negative.

Oghojafor (2012), in his study, evaluated Merger/Acquisition as an intervention strategy in the Nigerian banking sector. The objective was to identify whether this strategy has actually achieved the desired result for which it was intended, mostly in the 2005 merger in Nigeria. The study was carried out using both primary (questionnaire) and secondary (banks financial statements) data. 100 copies of questionnaire were administered on the management members of the selected banks. Out of the three tested hypotheses; hypothesis 1 result revealed the calculated t-statistics to be $\mathrm{t}=6.591 \mathrm{P}<0.05$, which implies that Merger and Acquisition had helped to curb the distress that would have occurred in the Nigeria banks during the period it was applied. On the other hand, Hypothesis two examines performances in pre and post merger. Agbada and Odejimi (2012) carried out study on Core Competences and Optimising Bank Capital Management in Nigeria. They adopted Competence predictors such as, knowledge, skill and attitude as their independent variables and Return on Capital Employed (ROCE), the common technique of measuring the size of returns derived from capital funds as their dependent variable. Their study however revealed a declining state of employees' core competences, implying that the necessary skill, knowledge, and attitude needed to efficiently control bank capital were lacking in a good percentage of employees under examination. Their empirical results was the reflection of the recruitment strategy that destabilized professionalism in academic qualification of bank employees which has been prevalent in the industry from the 1980s and may also serve as a lesson for relevant authorities in the industry.

Udoidem and Acha (2012) researched on corporate restructuring in Nigeria with prominence on merger and acquisition. Their work theoretically assessed the implications of mergers and acquisitions for economic growth, which revealed few mergers and acquisitions in the years prior to bank consolidation 2004 to 2005 . They also discovered that the exceptional numbers of mergers and acquisitions during bank consolidation led to the adoption of this period in the assessment of the impact of mergers and acquisitions on banks' performance. In order to achieve this, they compared the pre consolidated and post consolidated performance of banks unsing seven (7) years before 1997 to 2003 and seven (7) years after 2004 to 2010 bank consolidation in Nigeria in their analysis. They however concluded that Nigerian banks have slightly improved after consolidation. Adah (2012) examined the impact of recapitalisation on the financial performance of deposits money banks in Nigeria. The study adopted a correlation research design in which secondary data were mostly in use. For data analysis, the study employed the independent t-test to test difference between two means. In Ernest, (2012), a study was carried out on Bank Consolidation in Nigeria, with central focus on Marketing Implications and Challenges for the surviving Banks which Third world countries wishing to embark on the same exercise should watch out for. According to him, the Nigerian banking industry has witnessed and is still witnessing revolutionary metamorphosis in recent years as a result of the restructuring programmes channelled towards resolving the existing problems of the industry by the apex bank. In Oladele, Abosede, and Akeke, (2012), a research was carried out on "A Post Consolidation Assessment of Profitability in Nigerian Banks", which examined the profit efficiency of Nigerian banks after the recapitalization exercise by the apex bank (CBN) for the period of 2006-2008. According to them, the composition of financial service industries are swiftly 
changing; hence, it is of high necessity to evaluate the efficiency of developing institutions. Investors and creditors use such efficiency measurements to determine both present and past performance status of banks. Consequent to the growth of competition, enhancement of efficiency is a major priority of banks' management. The study found that the estimated profit efficiency scores of troubled banks for the periods; 2006, 2007 and 2008 were respectively $0.79,0.89$ and 0.94 , while the corresponding healthy banks' scores were respectively; $0.59,0.75$ and 0.86 for the periods; 2006, 2007 and 2008. The study concluded that profitability is not a good measure of performance.

\section{Methodology}

The cross sectional survey design was used for this research. Hence the study made use of a predefined group that is, the past audited financial statements of the selected banks were more appropriate for the study. The population of this study consists of all the twenty-two (22) deposit money banks in the Nigerian banking industry. This industry has been chosen because it is the prominent financial industry which requires regular performance evaluation.

The sample size for this study was determined in accordance with recommendation made by Adegbaju and Olokoyo (2008), which states that the researcher should try to obtain at least $1 / 10^{\text {th }}$ of the population he studies in his sample, i.e. any size above $1 / 10^{\text {th }}$ of the population is considered adequate. According to them, there is no satisfactory generalization on what the suitable sample size should be. Some authors all proposed that the sample size should be based on what use is to be made out of the outcome and how much precision the researcher desires. By applying this recommendation to the study gives total sample size of two (2) banks. However the researcher chose to increase the sample size to ten (10) banks out of the twenty-two (22) deposit money banks (DMBs) to enhance generalization.

The data for this research work is secondary and was extracted from the Annual Reports of the selected banks for a period of five (5) years (2008-2012). This is necessary in order to derive facts and figures from a secondary source which can be attested and proven at any point in time.

The study will adopt a simple Regression Analysis in analyzing data collected from the financial statement of each of the selected banks for a whole five years period from 2008 to 2012. The statistical method chosen for the analysis of the four identified hypotheses of this study is consistent with the statistical method used by, Oghojafor (2012) The analysis will be done using average figures from all data collected and the results of the study will be presented in tables.

\section{Data Presentation, Analysis And Discussion Of Result}

This section focuses on data presentation, analysis and interpretation, test of hypotheses and discussion of results drawn from the entire study. The presentation and analysis of the hypotheses formulated were carried out simultaneously in a standardized form. Hence, each tested hypothesis is divided into restatement of research objective, question and hypothesis; result of the analysis of the tested hypothesis; interpretation of parameter values of the tested hypothesis; and finally the discussion of results of the tested hypothesis.

\subsection{Test Of Hypothesis One}

\section{Result of Regression Test from Hypothesis One}

\section{Table 1}

Table 2

\begin{tabular}{|c|c|c|c|c|c|c|c|c|c|}
\hline \multirow[b]{3}{*}{ Model } & \multirow[b]{3}{*}{$\mathrm{R}$} & \multirow[b]{3}{*}{ R Square } & \multirow[b]{3}{*}{$\begin{array}{l}\text { Adjusted R } \\
\text { Square }\end{array}$} & \multicolumn{6}{|l|}{ Model Summary } \\
\hline & & & & \multirow[b]{2}{*}{$\begin{array}{l}\text { Std. Error of the } \\
\text { Estimate }\end{array}$} & \multicolumn{5}{|c|}{ Change Statistics } \\
\hline & & & & & $\begin{array}{l}\text { R Square } \\
\text { Change }\end{array}$ & $\begin{array}{c}\mathrm{F} \\
\text { Change }\end{array}$ & df1 & df2 & $\begin{array}{l}\text { Sig. F } \\
\text { Change }\end{array}$ \\
\hline 1 & $.007^{\mathrm{a}}$ & .000 & -.125 & 2.6044011365771 & .000 & .000 & 1 & 8 & .985 \\
\hline
\end{tabular}

a. Predictors: (Constant), PMACB (N'000)

b. Dependent Variable: DPS (Naira)

Source: SPSS Data

\begin{tabular}{|c|c|c|c|c|c|}
\hline Model & Sum of Squares & Df & Mean Square & $\mathrm{F}$ & Sig. \\
\hline 1 Regression & .003 & 1 & .003 & .000 & $.985^{\mathrm{a}}$ \\
\hline Residual & 54.263 & 8 & 6.783 & & \\
\hline Total & 54.266 & 9 & & & \\
\hline
\end{tabular}

a. Predictors: (Constant), PMACB (N'000)

b. Dependent Variable: DPS (Naira)

Source: SPSS Data 
Table 3

Coefficients

\begin{tabular}{|c|c|c|c|c|c|c|}
\hline \multirow{2}{*}{\multicolumn{2}{|c|}{ Model }} & \multicolumn{2}{|c|}{ Unstandardized Coefficients } & \multirow{2}{*}{$\begin{array}{c}\text { Standardized } \\
\text { Coefficients }\end{array}$} & \multirow[b]{2}{*}{$\mathrm{T}$} & \multirow[b]{2}{*}{ Sig. } \\
\hline & & $\mathrm{B}$ & Std. Error & & & \\
\hline 1 & $\begin{array}{l}\text { (Constant) } \\
\text { PMACB } \\
\text { (N'000) }\end{array}$ & $\begin{array}{r}1.487 \\
1.440 \mathrm{E}-10\end{array}$ & $\begin{array}{r}1.550 \\
.000\end{array}$ & .007 & $\begin{array}{l}.959 \\
.019\end{array}$ & $\begin{array}{l}.366 \\
.985\end{array}$ \\
\hline
\end{tabular}

a. Dependent Variable: DPS (Naira)

Source: SPSS Data

Table 4 Result of Pearson correlation test from hypothesis one

\section{Correlations}

\begin{tabular}{|c|c|c|c|}
\hline & & DPS (Naira) & PMACB (N'000) \\
\hline \multirow[t]{2}{*}{ Pearson Correlation } & DPS (Naira) & 1.000 & .007 \\
\hline & PMACB (N'000) & .007 & 1.000 \\
\hline \multirow[t]{2}{*}{ Sig. (1-tailed) } & DPS (Naira) & & .493 \\
\hline & PMACB (N'000) & .493 & \\
\hline \multirow[t]{2}{*}{$\mathrm{N}$} & DPS (Naira) & 10 & 10 \\
\hline & PMACB (N'000) & 10 & 10 \\
\hline
\end{tabular}

*. Correlation is significant at the 0.01 level (1-tailed).

Source: SPSS Data

\section{Parameter Values of Hypothesis One}

\begin{tabular}{|c|c|c|c|}
\hline & & & $\begin{array}{c}\text { DPS }=\mathrm{F}(\mathrm{PMACB})+u \\
\mathrm{~S}=\alpha(0)+\alpha(1) * \mathrm{PMACB}+u\end{array}$ \\
\hline DPS & 1.487 & + & 1.440 PMACB $+u$ \\
\hline Std. Error = & 1.550 & & .000 \\
\hline T- Statistics: & 0.959 & 0.019 & \\
\hline Prob (T- Statistics): & 0.366 & & 0.985 \\
\hline
\end{tabular}

$\mathrm{R}=0.007 \quad \mathrm{R}$-Square $\left(\mathrm{R}^{2}\right)=0.000 \quad$ Adjusted $\mathrm{R}$-Square $\left(\mathrm{R}^{-2}\right)=-0.125$

\subsection{Test of Significance}

Probability value is the most efficient test of significance. If probability value is greater than 0.05 ( $p>0.05$ ), then it is insignificant. The decision is to reject $\mathrm{H}_{1}$ and accept $\mathrm{H}_{0}$. Conversely if probability value is less than 0.05 ( $\mathrm{p}<0.05)$, this shows that it is significant. The decision is to reject $\mathrm{H}_{0}$ and accept $\mathrm{H}_{1}$.

From the result above, PMACB probability is 0.985 which is far greater than 0.05 . The decision therefore is to accept $\mathrm{H}_{0}$.

\section{Result of Regression Test from Hypothesis Two}

Table 6

Table 5

\begin{tabular}{|c|c|c|c|c|c|c|c|c|c|}
\hline \multicolumn{10}{|c|}{ Model Summary } \\
\hline \multirow[b]{2}{*}{ Mode } & \multirow[b]{2}{*}{$\mathrm{R}$} & \multirow[b]{2}{*}{$\begin{array}{c}\mathrm{R} \\
\text { Square }\end{array}$} & \multirow[b]{2}{*}{$\begin{array}{l}\text { Adjusted } \\
\text { R Square }\end{array}$} & \multirow[b]{2}{*}{$\begin{array}{l}\text { Std. Error of the } \\
\text { Estimate }\end{array}$} & \multicolumn{5}{|c|}{ Change Statistics } \\
\hline & & & & & $\begin{array}{c}\text { R Square } \\
\text { Change }\end{array}$ & $\begin{array}{c}\mathrm{F} \\
\text { Change }\end{array}$ & df1 & df2 & $\begin{array}{c}\text { Sig. F } \\
\text { Change }\end{array}$ \\
\hline 1 & $.091^{\mathrm{a}}$ & .008 & -.116 & 1.0923867914968 & .008 & .067 & 1 & 8 & .803 \\
\hline
\end{tabular}

\begin{tabular}{|ll|r|r|r|r|r|}
\hline Model & & Sum of Squares & Df & Mean Square & F & \multicolumn{1}{c|}{ Sig. } \\
\hline 1 & Regression & .079 & 1 & .079 & .067 & $.803^{\mathrm{a}}$ \\
& Residual & 9.546 & 8 & 1.193 & & \\
& Total & 9.626 & 9 & & & \\
\hline
\end{tabular}

a. Predictors: (Constant), PMACB (N'000)

b. Dependent Variable: EPS (Naira)

Source: SPSS Data 
Table 7

Coefficients $^{\mathrm{a}}$

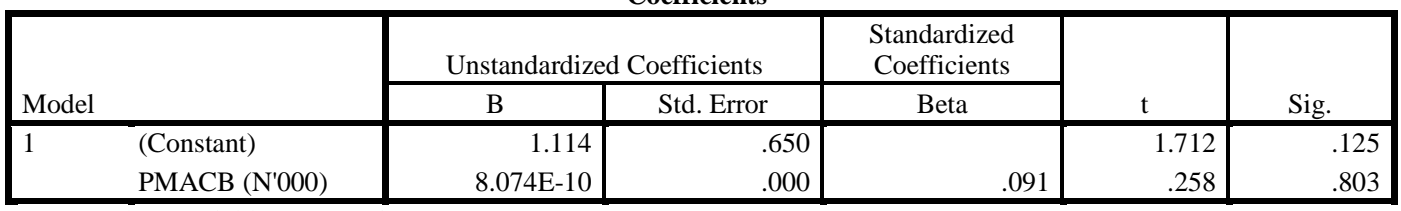

a. Dependent Variable: EPS (Naira)

Source: SPSS Data

Table 8 Result of Pearson correlation test from hypothesis two

\begin{tabular}{|c|c|c|c|}
\hline \multicolumn{4}{|c|}{ Correlations } \\
\hline & & EPS (Naira) & PMACB (N'000) \\
\hline \multirow[t]{2}{*}{ Pearson Correlation } & EPS (Naira) & 1.000 & .091 \\
\hline & PMACB (N'000) & .091 & 1.000 \\
\hline \multirow[t]{2}{*}{ Sig. (1-tailed) } & EPS (Naira) & & .401 \\
\hline & PMACB (N'000) & .401 & \\
\hline \multirow[t]{2}{*}{$\mathrm{N}$} & EPS (Naira) & 10 & 10 \\
\hline & PMACB (N'000) & 10 & 10 \\
\hline
\end{tabular}

**. Correlation is significant at the 0.01 level (1-tailed).

Source: SPSS Data

\subsubsection{Parameter Values of Hypothesis Two}

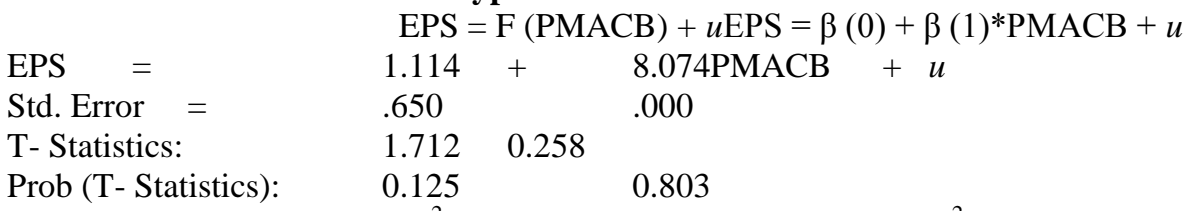

$R=0.091 \quad$ R-Square $\left(R^{2}\right)=0.008 \quad$ Adjusted $R$-Square $\left(R^{-2}\right)=-0.116$

Probability value is the most efficient test of significance. If probability value is greater than 0.05( $\mathrm{p}>0.05$ ), then it is insignificant. The decision is to reject $\mathrm{H}_{1}$ and accept $\mathrm{H}_{0}$. Conversely if probability value is less than $0.05(\mathrm{p}<0.05)$, this shows that it is significant. The decision is to reject $\mathrm{H}_{0}$ and accept $\mathrm{H}_{1}$. From the result above, EPS probability is 0.803 which is far greater than 0.05 . The decision therefore is to accept $\mathrm{H}_{0}$.

\section{Conclusion}

Attempts have been made in this study to assess the impact of mergers and acquisition in the Nigerian banking industry as regards its performance, profitability and the economy at large. With respect to the analysis carried out, it is obvious that mergers and acquisition (M\&A) has not significantly improved performance and profitability of Deposit Money Banks in Nigeria, which in essence, has not enhanced survival and control of deposit money banks in Nigeria.

The study reveals that the post merger and acquisition has no significant effect on dividend per share of shareholders, their earnings per share, return on assets and return on capital employed.

In addition, it is worthy of note that consolidation through mergers and acquisitions (M\&A) has resulted into little or no changes in the capital structure of the banking industry. Hence, it has encouraged centralization of ownership in the hands of few shareholders in the post consolidation exercise in Nigeria. Despite various discoveries by various researchers that there is no relationship between capital base of the banks and their performance level, this study in contrary revealed that there is positive relationship though not quite significant.

In a broad perspective, this study further revealed that there is a reduction in the degree of global banking crisis over the years and thus reduction in the general banking failure particularly in Nigeria. This is made possible through mergers and acquisition process which consecutively resulted in increased capital base of banking industry in Nigeria

\section{References}

[1]. Abdulkadir, R. I. (2007). Financial statement analysis as a measure of performance; A case study of chevron oil producing, Nigeria. a seminar paper presented at the Department of Accounting. Kano: Bayero University.

[2]. Agbada, A. O., and Odejimi, D. O. (2012). Core Competences and Optimising Bank Capital Management in Nigeria. International Journal of Financial Research, 4(1). doi:10.5430/ijfr.v4n1p75 
[3]. Abdulraheem, A., Yahaya, K. A., and Aliu, O. A. (2011). Determinants of Performance: A Cross Generational Analysis of Nigerian Banks. European Journal of Social Sciences, 24(4).

[4]. Adah, A. (2012). Impact of Recapitalisation on the Financial Performance of Deposits Money Banks in Nigeria. A Dissertation submitted to the Post graduate school. Zaria: Ahmadu Bello University.

[5]. Adegbaju, A. A., and Olokoyo, F. O. (2008). Recapitalization and Banks' Performance: A Case Study of Nigerian Banks. African Economic and Business Review, 6(1)

[6]. Bakare, A S;. (2011). The trend and growth implications of bank recapitalization in Nigeria. African Journal of Business Management, 5(14), 5938-5945. doi:DOI: 10.5897/AJBM10.443

[7]. Barros, C. P., and Caporale, G. M. (2012). Banking Consolidation in Nigeria, 2000-2010. In Economics and Finance Working Paper Series (Vol. 12, pp. 1-24). London: Brunel University. Retrieved from http://www.brunel.ac.uk/economics

[8]. Beaver, W. H., Correla, M., and Mcnichols, M. F. (2012). Financial Statement Analysis and the Prediction of Fianancial Distress, Foundations and Trends in Accounting. In W. H. Beaver, M. Correla, M. F. Mcnichols, and S. A. Zeff (Ed.), Book Reviews (Vol. 87, pp. 1445 - 1455). Hanover, MA Publisher Inc. doi:DOI: 10.2308/accr-10278

[9]. Beck, T., Demirguc-Kunt, A., and Levine, R. (2007, January). Bank Concentration and Fragility. Impact and Mechanics. National Bureau of Economic Research. Retrieved from http://www.nber.org/books/care06-1

[10]. Buyuksalvarci, A., and Abdioglu, H. (2011). Determinants of capital adequacy ratio in Turkish Banks: A panel data analysis. African Journal of Business Management, 5(27), 11199-11209.

[11]. Central Bank of Nigerian Annual Report. (2003). Annual Report. CBN, Abuja.

[12]. Cetin, K. M., and Cetin, I. E. (2010). Multi-Criteria Analysis of Banks' Performances. International Journal of Economics and Financial Studies, 2(2).

[13]. Dogan, M., and Yildiz, F. (2013). The Impact of the Board of Directors' Size on the Bank's Performance: Evidence from Turkey. European Journal of Business and Management, 5(6).

[14]. Ernest, I. E. (2012, May 3). Bank Consolidation in Nigeria: Marketing Implications and Challenges for the Surviving Banks. Arts and Social Sciences Journal, 2012, 1-15.

[15]. Gazia, Jamil S; Najmus, Sahar S;. (2013, January - June). Comparative Analysis of Four Private Sector Banks as per CAMEL Rating. Business Perspectives and Research.

[16]. Hosono, S. K., and Tsuru, K. K. (2006). Consolidation of Corporative Bank (shinkin) in Japan: Motives and Consequences. RIETI Discussion paper.

[17]. Khadijat, A. Y., Abdulrasheed, A., Ramat, T. S., and Oyebola, F. E.-M. (2012, March). Relationship between Level of Compliance with Statement of Accounting Standards and Performance of Nigerian Banks. International Journal of Business and Management, 7(6). doi:10.5539/ijbm.v7n6p128

[18]. Kumbirai, M., and Webb, R. (2010). A Financial Ratio Analysis of Commercial Bank. African Review of Economics and Finance, 2(1).

[19]. Mojirade, A. D. (2011). Capital Base and The Performance of Commercial Banks in Nigeria: Pre and Post Consolidation Era. Graduate Studies Redeemer's University.

[20]. Nguyen, K. M., Giang, T. L., and Nguyen, V. H. (2013, January 14). Efficiency and Super-Efficiency of Commercial Banks in Vietnam: Performances and Determinants. Asia-Pacific Journal of Operational Research, $30(1)$, 19. doi:10.1142/S0217595912500479

[21]. Nuraddeen, U. M. (2011). Impact of Bank Consolidation on the Performance of Banks in Nigeria. Being a Thesis Submitted to the Post Graduate School, Department of Accounting , 1-91. doi:MSC/ADMIN/10317/07-08

[22]. Oghojafor, B. E. (2012, May 1). Evaluating Mergers and Acquisition as Strategic Interventions in the Nigerian Banking Sector: The Good, Bad and the Ugly. International Business Research, 5(5). doi:10.5539/ibr.v5n5p147.

[23]. Oladele, P. O., Abosede, A. J., and Akeke, N. I. (2012). A Post-Consolidation Assessment of Profitability in Nigerian Banks. Journal of Social and Development Sciences, 3(1), 1-5.

[24]. Oladele, P O; Sulaimon, A A; Akeke, N I. (2012 ). Determinant of bank Performance In Nigeria. International Journal of Business and Management Tomorrow, 2(2). Retrieved from http://www.ijbmt.com

[25]. Olajide, R. A. (2010). Mergers and Acquisitions (M\&As) in the Nigerian Banking Industry: An Advocate of three Mega Banks. European Journal of Social Sciences, 15(4), 1-10.

[26]. Somoye, R. O. (2008). The Performances of Commercial Banks in Post-Consolidation Period in Nigeria: An Empirical Review. European Journal of Economics, Finance and Administrative Sciences(14).

[27]. Sulaimaon, A. A., Akeke, N. I., and Fapohunda, F. M. (2011). Capital Reforms And Performance of Nigerian Banking Sector. International Journal of Business and Management Tomorrow (IJBMT), 1(3), 1-5. Retrieved from www.ijbmt.com

[28]. Udoidem, J. O., and Acha, I. A. (2012). Corporate Restructuring through Mergers and Acquisition:Experience from Nigeria. Journal of Economics and Sustainable Development, 3(13).

[29]. Uyen, D. (2011). The CAMEL Rating System in Banking Supervision A Case Study. Arcada University of Applied Sciences International Business. 